\title{
VALLE INCLÁN Y LA PREFIGURACIÓN DEL ESPERPENTO. ANÁLISIS DE LA PIPA DE KIF
}

\author{
por \\ EVA VALCÁRCEL
}

\section{DEL DECADENTISMO AL ESPERPENTISMO}

El proceso poético de Valle-Inclán se caracteriza por su especial transformación, pasando de los códigos estéticos del modernismo a la desnuda y comprometida representación de carácter expresionista, del mundo rural gallego. La pipa de kif ${ }^{\prime}$, adopta una estética de transición entre estas dos prácticas tan alejadas. Sin eliminar totalmente las connotaciones, el ritmo musical y el artificio de los componentes exóticos, proclama su decisión de crear la "musa moderna"2. En esta nueva práctica literaria se inscriben dos tendencias estéticas: el decadentismo y el funambulismo.

Valle-Inclán engarza, en las claves de esta obra, funciones presentes en la literatura de fin de siglo, por ejemplo, en su Sonata de estío (1903). Al exotismo geográfico, oriental o americano, se unen los efectos degradadores

\footnotetext{
' Primera edición, Madrid, Sociedad General Española de Librería, 1919. Compilado en Claves líricas, Madrid, Pueyo, 1930.

${ }^{2}$ Cfr. las siguientes citas en La pipa de kif, Sociedad Española de Librería, Madrid, 1919, pp. 21 y 35 :

"¿Acaso esta musa grotesca / -ya no digo funambulesca- / que con sus gritos espasmódicos / irrita a los viejos retóricos, / y salta lucienco la pierna, / no será la musa muderna?".

"Cubista, futurista yestridente, / por el caos febril de la modorra / vuela la sensación que al fin se borra, / verde mosca, zumbándome en la frente."
}

"CUADERNOS DE ESTUDIOS GALLEGOS", Tomo XLI, Fascículo 106, Santiago 1993-94. 
de los estupefacientes. Se mantiene el despliegue del mundo del próximo y del lejano Oriente: los bosques sagrados de Anán, la Arabia feliz, Indostán, China y Sumatra. En éstos ámbitos se enmarcan exóticos personajes femeninos como Belkis, Cleopatra, odaliscas y sultanas? ${ }^{3}$.

Las estructuras métricas se apoyan en las cuatro unidades preferidas por los poetas modernistas: dodecasílabos, alejandrinos, decasílabos y eneasílabos, combinados en los modelos estróficos tradicionales. A pesar de ésta práctica común, el escritor gallego renueva los esquemas rítmicos y adapta los periodos enfáticos, heroicos, melódicos y sáficos a la conceptualización semántica. Emplea, además, rimas inarmónicas, ripios intencionados y connotaciones degradadoras.

A través de las dieciocho claves del texto, el poeta va sustituyendo las sensaciones cromáticas ruberianas por los fuertes contrastes expresionistas. Sin prescindir del alejamiento exótico, acude a la representación de referentes objetivos y descubre, por ejemplo, la marginación y la cruda existencia del suburbio madrileño. Las connotaciones plásticas, la belleza artificiosa contrasta con las formas cabalísticas y con las deformaciones caricaturescas. Los animales, las aves simbólicas del modernismo sugieren percepciones e imágenes que se transforman en imágenes visionarias, como en estos ejemplos:

$$
\begin{array}{lcl}
\text { - la jirafa } & \text { (evoca) la silueta de Sara Bernhardt } \\
\text { - la Arabia feliz (vista) a través de los ojos de una cabra } & \text { - el pavo real } & \text { (es) una llama del Paraíso Terrenal }
\end{array}
$$

En la reelaboración de las formas del lenguaje literario, resaltan las transmutaciones sinestésicas, y la reiteración de las emisiones auditivas atribuidas a componentes cromáticos. Seleccionamos algunos ejemplos:

$$
\begin{gathered}
\text { "grito azul" } \\
\text { "voz azul" } \\
\text { "cantan en la entraña del azul" } \\
\text { "En mi pipa el humo da su grito azul" } \\
\text { "El amor provoca con su voz azul" }
\end{gathered}
$$$$
\text { "En mi pipa el humo da su grito azul" }
$$

El exotismo oriental y americano, además de la estética del decadentismo finisecular conforman los versos de varias claves. Los pro-

\footnotetext{
${ }^{3}$ El exotismo geográfico y el hedonismo aparecen representados en la clave "La tienda del herbolario". Cfr. Susana ITZOVICH de YURKIEVICH, "América en la técnica discursiva de Valle-Inclán", en Estudios reunidos en conmemoración del centenario, La Playa, Universidad Nacional, 1967, pp. 379-393.
}

"CUADERNOS DE ESTUDIOS GALLEGOS", Tomo XLI, Fascículo 106, Santiago 1993-94. 
cedimientos estéticos modernistas se reiteran en la clave "La tienda del herbolario", modelo de exotismo basado en las experiencias americanas del escritor. Las resonancias ruberianas se manifiestan en la pluralidad de las sensaciones y en el juego de las sinestesias. En los siguientes versos, a modo de ejemplo, descubrimos cómo las percepciones olfativas se cargan de significado sensual:

"olor de senos... tras las rejas"

"olor divino... de la mulata"

"ardiente esencia de la canela... encomio de la mozuela"4

El efecto obnubilador de los estupefacientes, se mezcla con signos de carácter mítico, con misterios y funciones de nigromancia, para perfilar los paraísos artificiales. El mismo título del libro, La pipa de kif, sintetiza su contenido.

\section{EL PROCESO DE LA RENOVACIÓN POÉTICA}

Desde la primera clave de La pipa de kif, Valle-Inclán enlaza sintagmas y lexías que alteran la representación modernista de los componentes referenciales. Pero además, el ritmo cinético de algunos versos y la creación de imágenes visionarias nos descubre una nueva estética. Lo podemos constatar en el segundo cuarteto cruzado, dodecasilábico:

"Con rítmicos saltos plenos de alegría, cabalga en el humo de mi pipa Puk, su risa en la entraña del azul del día mueve el ritmo órfico amado de Gtuk" ${ }^{15}$

El ritmo cinético desborda las acciones reales. Los saltos del personaje demónico de la tradición medieval, que había sido dramatizado por Shakespeare, adquiere la cualidad irreal de poder cabalgar sobre el inconsciente, el humo de la pipa de Puk.

En las estrofas siguientes, se introduce la función de los estupefacientes, literaturizados por las obras decadentistas finiseculares. Pero en la última estrofa de la clave, la dependencia, la condición de adicto, se resuelve con ironía:

\footnotetext{
${ }^{4}$ Id., Id., pp. 150-151.

5 "¡Aleluya!", La pipa de kif, ed. cit., pp. 15-23.
} 
"Si tú me abandonas, gracia del hachic, me embozo en la capa y apago la luz. Ya puede tentarme la Reina del Chic: no dejo la capa y le hago la $+" 6$

La voluntad de cambio estético y temático se confirma en la segunda clave, titulada "¡Aleluya"7. Desde las primeras unidades, confiesa la "ventolera" de escribir versos funambulescos, de seguir la línea de Banville ${ }^{8}$.

"De hacer versos funambulescos

uno purista diría grotescos

con el punto de extravagancia que Banville ha tenido en Francia".

En los pareados siguientes se enfrenta a los escritores convencionales, arcaizantes y critica a los eruditos, a los académicos. Representa en actitudes cómicas, grotescas a Cejador, Cotarelo, Pérez de Ayala, Ricardo León, porque han criticado sus versos. Decide, además, romper las rígidas leyes del verso y proclama una nueva etapa convulsionada en estos tres pareados eneasilábicos:

"En mi verso rompo los yugos

y hago la higa a los verdugos

Yo anuncio la era argentina

de socialismo y cocaína.

De cocotas con convulsiones

y de vastas revoluciones" ${ }^{\prime \prime}$

Como hemos apuntado en una nota anterior, Valle-Inclán, en los últimos pareados de "¡Aleluya!", invoca a la musa grotesca, funambulesca, identificables con la musa moderna.

La estilización, la técnica caricaturesca, la transmutación esperpéntica, se consolida en la clave quinta, titulada "Bestiario". Las reiteradas visitas del escritor gallego a la Casa de Fieras del Buen Retiro son la fuente de inspiración para las dieciocho unidades estructuradas en estrofas de pie

\footnotetext{
rior.

${ }^{6}$ Compárese con el texto de Farsa y licencia de la Reina Castiza, en el capítulo ante-

${ }^{7}$ La pipa de kif, ed. cit., pp. 15-23.

${ }^{8}$ Id., Id., pp. 25-32.

${ }^{9}$ Id., Id., p. 26.
}

"CUADERNOS DE ESTUDIOS GALLEGOS", Tomo XLI, Fascículo 106, Santiago 1993-94. 
quebrado. La intención satírica, la estrategia de calificaciones expresionistas, impone una selección continuada de lexemas y lexías de significado degradador que se manifiestan en imágenes caricaturescas, disparatadas, prosopopéyicas y zoomórficas. Estos procesos configuran un antilirismo sin concesiones.

La serie de especímenes zoológicos se inicia con el doble sentido paródico de la segunda estrofa:

"Y me detuve emocionado

ante aquel viejo carcamal

estilizado

en el escudo nacional"10

Entre rejas, el viejo león bosteza, sacude la crin; muestra en sus "arrugas" la pesimista cualidad humana del "esplín". Cada animal se perfila en silueta desquiciada, resaltada por trazos desmesurados. El canguro antediluviano da saltos "de flin-flan" y esconde sus crías en "el buche de acordeón". El tigre se agita ondulante, tras los hierros, con el belfo tremante", la "garra rampante y el ojo hostil". La alusión satírica a la curia se relaciona con los actos gestuales del lobo.

Los trazos zoográficos se mezclan, frecuentemente, con factores antropológicos. Frente al zoomorfismo dominante en la obra valleinclanesca, los factores zoológicos se identifican con personajes. El canguro tiene "trazas de alemán"; el leopardo exhibe la "impertinencia del inglés"; el índico elefante sueña como "un fakir". La cotorra viste "una falda que fue de la Infanta Isabel". El oso "recuerda al conde Tolstoy". El diseño de la jirafa se amplía con atributos de distintos campos referenciales; es un "disparate pintoresco"; agria como una solterona; alcanza la cúpula del laurel; simula un elemento arquitectónico bizantino; emula la silueta de la gran actriz francesa Sara Bernhardt; siluetea el arabesco "del caballo de ajedrez":

"Y la romántica jirafa, solterona que bebe hiel, las rosas chafa en la cúpula del laurel.

¡Arquitectura bizantina, imposible de razonar,

${ }^{10}$ Id., Id., p. 29.

"CUADERNOS DE ESTUDIOS GALLEGOS", Tomo XLI, Fascículo 106, Santiago 1993-94. 


\author{
de la divina \\ silueta de Sara Bernhardt! \\ Un disparate pintoresco, \\ maravilloso de esbeltez, \\ el arabesco \\ del caballo del ajedrez ${ }^{11}$
}

\section{LOS PROCEDIMIENTOS ESPERPÉNTICOS}

Valle-Inclán demuestra en La pipa de kif su decisión renovadora. Aunque mantiene las estructuras métricas tradicionales y engarza connotaciones de raíz ruberiana, somete la lengua a un proceso de semiotización. Selecciona lexemas y sintagmas de significado paródico, degradador, a veces disparatado. Sigue empleando el cromatismo, pero intensifica sus matices con técnica solanesca, introduciendo colores vivos, calientes: rojo, amarillo, malva, escarlata.

Los brochazos intensos, vigorosos, están sometidos, en bastantes versos, a la función lúdica de la sinestesia, de la imagen visionaria. El cambio operativo en el campo de la expresión, se manifiesta en la reiteración de connotaciones y lexías deformantes. Por este cambio estilístico, La pipa de kif puede evaluarse como una anticipación de la teoría del esperpento. El primer modelo ilustrativo es la composición "Fin de carnaval"12.

En sus cuartetas de pie quebrado, se interpretan, con un contraste de imágenes y metáforas, escenas populacheras, "pobretería y locura", funtivos deshumanizadores. El mundo festivo, exhibicionista, está alterado por canciones, mascaradas y gritos soeces.

Los prototípicos personales de la Commedia dell'arte reaparecen, para interpretar su papel en el ritual carnavalesco, identificados con un grupo social suburbano. La figura de Colombina se degrada por su exudación olfativa:

$$
\begin{gathered}
\text { "Los pingos de Colombina } \\
\text { derraman su olor } \\
\text { de pacholí y sobaquina } \\
\text { ¡Y vaya calor!" }
\end{gathered}
$$

\footnotetext{
"Id., Id., pp. 39-50.
}

${ }^{12}$ Id., Id., pp. 40-41.

"CUADERNOS DE ESTUDIOS GALLEGOS", Tomo XLI, Fascículo 106, Santiago 1993-94. 
Pierrot, con el rostro pintado, frecuenta la taberna en compañía de la "tarasca", maquillada de colores vivos, chillones:

"Un Pierrot junta en la tasca

su blanco de zin,

con la pintada tarasca

de blanco y carmín"13

La intensificación cromática, característica de la técnica esperpéntica, resalta la presencia de concurrentes al entierro de la Sardina. En conjunción con las estridencias cromáticas y el "ciclón" estentóreo de latas, sartenes y calderos, sobresalen las máscaras, las voces desarticuladas, los borrachos de rostros adulterados por la máscara y la indumentaria del disfraz:

"Al pie de un farol, sus flores abre el pañolón de la chula: sus colores alegrías son."

La decoración festiva de globos de colores y flores de confetti y la materia "melancólica" del acordeón, destacan en la tarde gris y fría, del Miércoles de Ceniza. Sus signos caracterizadores negativos, con su itensificación deformadora, se vinculan para González López ${ }^{14}$, con "los rasgos caricaturescos de Goya o de su discípulo Alenza".

Las sospechosas exhibiciones de mujeres pintarrajeadas dinamizan las sucesivas secuencias expresionistas. El garbeo femenino, con el vaivén del "pay-pay" y el ondear de sus flecos, contrastan los gritos soeces de los "curdas" y su desmesurada deformación de máscaras, como este modelo:

"El curdela narigudo blande un escobón:

- Hollín, chistera, felpudo, nariz de cartón-"

La estrategia esperpéntica se intensifica en la secuencia "macabra" del entierro de la Sardina, pervivencia de la tradición del campo antropológico cultural:

"Absurda tarde. Macabra mueca de dolor.

Se ha puesto el Pata de Cabra mitra de prior.

${ }^{13}$ Id., Id., p. 41

${ }_{14}$ Emilio GONZÁLEZ LÓPEZ, La poesía de Valle-Inclán. Del simbolismo al expresionismo, San Juan, Universidad de Puerto Rico, 1973, p. 83.

"CUADERNOS DE ESTUDIOS GALLEGOS", Tomo XLI, Fascículo 106, Santiago 1993-94. 


\author{
Incerteza vespertina, \\ lluvia y vendaval: \\ entierro de la Sardina, \\ fin de Carnaval." 15
}

\title{
EL CIRCO DE LONA
}

El dinámico protagonismo popular de la clave "El circo de lona"16 se interpreta con procedimientos esperpénticos. Su prolongado discurso poético se estructura en tres unidades de métrica y estrategia estilística cambiantes. Las estrofas de pie quebrado del primer bloque representan el ambiente exterior, la masificación de las gradas y el deambular exhibicionista en la pista.

Quiebran la quietud del crepúsculo las estridencias musicales y el vocerío desatado. Las distorsiones representadas por lexemas y lexías sometidas a una estrategia intensificadora, nos transmiten una constante intención satírica. El público que procura sus entradas, es caracterizado con los signos negativos de este verso: "La chusma negra y pelona". A esta triple descalificación se une el diseño siluetado de la taquillera:

"La Pepona con mitones

moño y rizos de canela,

y el talle con alusiones

de vihuela." 17

A través de la serie de estrofas de pie quebrado, se suceden los primeros planos de los movimientos del mono, la cotorra sola escarlata de la cortina, las carcajadas del payaso, la lucha del coloso y la leona, los sables dorados de los chinos, las gayas banderas. Y el empaste sucesivo de fuertes sensacines olfativas y estridentes notas auditivas.

La caricatura de los artistas está conseguida mediante dos fórmulas de acumulación de apuntes extraídos de sus exhibiciones, que se suceden en contrapunto. La técnica esperpéntica de caracterización afecta tanto al proceso de deformación de las personas o animales, como a los elementos del espacio. Veamos algunos ejemplos: "agrio y desvencijado organillo",

\footnotetext{
${ }^{15}$ La pipa de kif, ed. cit., p. 29.

${ }^{16}$ Id., Id., pp. 51-69.

${ }^{17}$ Id., Id., p. 52.
}

"CUADERNOS DE ESTUDIOS GALLEGOS", Tomo XLI, Fascículo 106, Santiago 1993-94. 
"nota verde rabiosa de la cotorra", "sombra que se encalabrina", "trapecios volantes".

En la tercera parte del poema, el autor retoma la estructura de estrofas de pie quebrado. La marginación, el mobiliario desbaratado, la "sombra del hambre" se proyectan sobre el ruedo. El código restringido de la lengua conforma un antilirismo voluntario, basado en la deformación de las connotaciones, en la construcción de lexías degradadoras, paródicas, devaluadoras de los actos gestuales y los comportamientos morales.

Mediante un acercamiento en perspectiva dislocada, Valle-Inclán representa a los artistas en la intimidad, al despojarse de sus disfraces, exhibiendo su desnudez física y moral. Los sucesivos modelos humanos, intensificados por la actitud comprometida del autor, nos acercan a intensos perfiles sociales y delimitan el duro survey de un precario grupo laboral. La visión plural, fragmentada, se reconstruye con una perspectiva mixta de alejamiento y aproximación.

La textualización de las distintas imágenes oscila entre las siluetas transparentes y los leones que se desperezan tras los hierros y el encuadre próximo, avivado, de la mujer sentada:

$$
\begin{gathered}
\text { "A su lado una mozuela, } \\
\text { luciendo el roto zancajo, } \\
\text { recose la lentejuela } \\
\text { de un pingajo. } \\
\text { Y las falsas pantorrillas } \\
\text { dando gritos de falsete, } \\
\text { se tuercen en las canillas } \\
\text { bajo un siete."18 }
\end{gathered}
$$

La refracción especular nos ofrece el relieve objetivo del payaso que borra su maquillaje:

$$
\begin{gathered}
\text { "El payaso ante el espejo } \\
\text { se despinta con cerote } \\
\text { y se arranca el entrecejo } \\
\text { de pelote." } 19
\end{gathered}
$$

La exhibiciones circenses encadenadas aparecen enfocadas con una perspectiva deformadora de tipo expresionista que podemos denominar

\footnotetext{
${ }^{18}$ Id., Id., p. 66.

${ }^{19}$ Id., Id., p. 67.
}

"CUADERNOS DE ESTUDIOS GALLEGOS", Tomo XLI, Fascículo 106, Santiago 1993-94. 
como preesperpéntica, en lo que posee un protagonismo real el vértigo, junto al color estridente.

González López ${ }^{20}$ ha vinculado "El circo de lona" con el expresionismo y ha subrayado el tratamiento que Valle-Inclán da al tema del dolor de "los desgraciados y desvalidos" artistas del circo, que deben hacer reír a los demás, profesionalmente. El discurso poético de "El circo de lona" se estructura en catorce secuencias sometidas a un ritmo apremiante. Podemos visualizar esta estructura y su sucesividad en el cuadro siguiente:

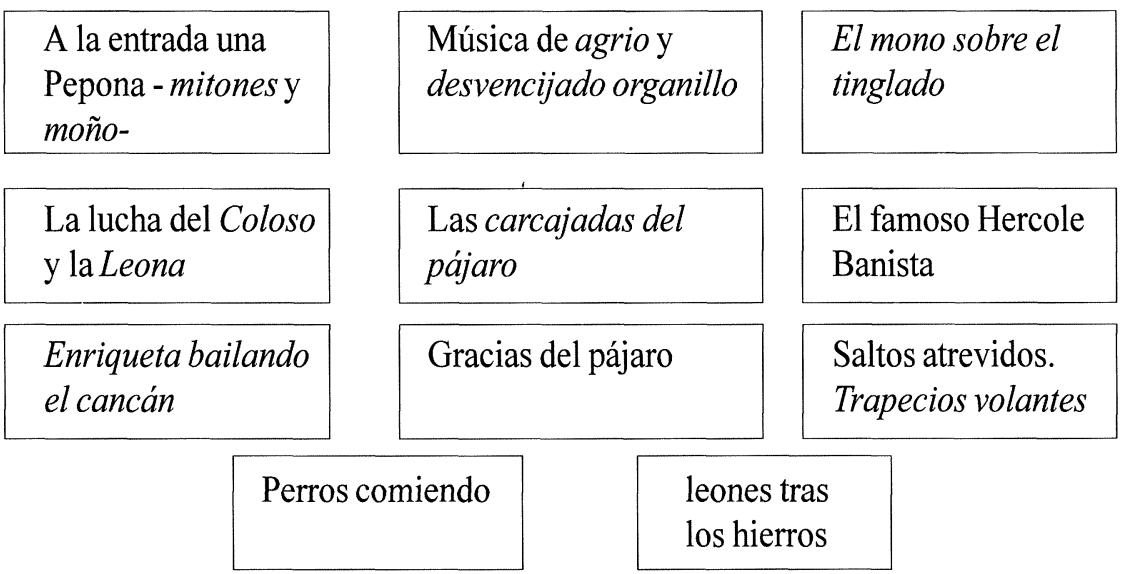

\section{LAS FUNCIONES TRÁGICAS EN EL CRIMEN DE MEDINICA}

La estructura multisensorial de La pipa de kif se concentra en las claves VII-XIV, en el proceso generativo del microdiscurso "El crimen de Medinica"21. En estas ocho claves, Valle-Inclán utiliza un proceso de relación entre significante y significado lingüístico muy distinto al de su etapa modernista. Su intención degradadora impone una selección de lexemas y lexías que prefiguran su estética expresionista: contrastes cromáticos, distorsiones, calificaciones paródicas. Con esta estrategia poetizadora, logra un texto insólito en la literatura española de aquellos años.

Para la construcción de los episodios tensionales del crimen, el escritor gallego recurre a la ruptura de la secuenciación temporal; y engarza,

\footnotetext{
${ }^{20}$ Op. cit., pp. $90-91$.

${ }^{21}$ La pipa de kif, ed. cit., p. 71-119.
}

"CUADERNOS DE ESTUDIOS GALLEGOS", Tomo XLI, Fascículo 106, Santiago 1993-94. 
entre las funciones cardinales, espacios de tiempo vacíos de acción, ocultaciones, signos de indicio.

La acreditada competencia valleinclanesca en los campos de la novela y el teatro influye en la hábil construcción de este discurso poético. La estructura de las funciones diegéticas reproduce una técnica pictórica, con una multiplicación de escenas que nos recuerdan los rectángulos toscamente pintados en un cartelón de ciegos. En las tres primeras claves nos introduce en los espacios concretos de la diégesis; y nos presenta a los agentes de la historia criminal; el jaque asesino y la víctima cruenta doña Estefaldina. En las cuatro unidades siguientes se dramatiza el proceso generativo del crimen.

Podemos sintetizar la pluralidad del desarrollo agencial con este diagrama:

Protagonistas y escenarios

Clave VII

Presentación del Jaque
Un figón
Clave VIII

Descripción de Medinica
Clave IX

Infanzona doña

Estefaldina Casona

Funciones trágicas del crimen

Clave X

\begin{tabular}{|l|}
\hline $\begin{array}{l}\text { Sueño agorero } \\
\text { de la Infanzona }\end{array}$ \\
Tijeras abiertas
\end{tabular}

Clave XI

Habitación de

la coima

El jaque puñal

ensangrentado
Clave XII

La Guardia
Civil conduce
al jaque
asesino

Clave XIII

Patíbulo reo en capilla

Ejecución

El microdiscurso de la clave VII, compuesto en sextetos dodecasilábicos, diseña el entorno del mesón del camino de Medinica, frecuentado por arrieros, mozos de mulas, jugadores, bigardones, jaques. La técnica simultaneísta de la cadena de componentes referenciales se esperpentiza en la interpretación de la atmósfera de la negra cocina, enrarecida por el humo, por los acres olores de magras de cecina y "sopas cáusticas de ajo y pimentón".

"CUADERNOS DE ESTUDIOS GALLEGOS", Tomo XLI, Fascículo 106, Santiago 1993-94. 
En este retablo popular, destaca, en primer plano, el diseño del Jaque, logrado con una técnica esperpéntica, con la acumulación de sintagmas degradadores, en estos tercetos dodecasilábicos:

"La jeta cetrina, zorongo a la cuca, fieltro de catite, rapada la nuca, el habla rijona, la ceja un breñal.

Cantador de jota, tirador de barra, bebe en la taberna, tañe la guitarra, la faja violeta esconde un puñal."22

El cuchillo en la faja, es un signo de indicio maléfico que se reitera. Es el mismo puñal "ensangrentado", instrumento del asesinato de la infanzona. Sin embargo, no hay otro síntoma en el comportamiento del jaque, que merienda con los bigardones: Sólo, "en medio del juego hablan sonsoniche", como confabulándose:

"El Jaque merienda con dos bigardones de fusta, zamarro, roñosos zajones y gorra orejera de pelo de can. Hecha la merienda juegan al boliche, en medio del juego hablan sonsoniche, demandan el gasto, pagan y se van."23

Desde el figón, se divisan, resplandecientes, en perspectiva los tejados de la villa lejana. Aunque no se cita el nombre de Medinica, éste es un anuncio de su protagonismo posterior, y lo es también del robo y del trágico parricidio.

En la clave siguiente se dibujan los espacios pueblerinos de "Medicina". Gracias a la fluidez narrativa de las redondillas, Valle-Inclán puede adoptar una perspectiva externa y objetiva, de amplio predominio nominal.

Mediante un procedimiento simultaneísta, se encadenan ocho planos impregnados de verismo y de sugerencias de ambiente: soportales, patios de mesones, corrales, tenderetes de la feria, cigüeñas y rastrojo. Además, y como indicio relevante aparece el "palacio de los Vargas", espacio del sacrificio mortal.

El ambiente del pueblo se completa en la clave "La Infanzona de

\footnotetext{
${ }^{22}$ Id., Id., p. 72.

${ }^{23}$ Id., Id., p. 73.
}

"CUADERNOS DE ESTUDIOS GALLEGOS", Tomo XLI, Fascículo 106, Santiago 1993-94. 
Medinica". Con la misma continencia lingüística y una perspectiva externa, resaltan los sucesivos encuadres. En el gran balcón saledizo, doña Estefaldina, con mitones, cofia y pañoleta, teje su calceta y contempla el desfile de seminaristas, la recua de mulos, el zig-zag del vuelo de un vencejo, los gorriones en el alero. Pero además, en los sextetos dodecasílabos, se encuadra el retrato moral de la infanzona, con una evidente intencionalidad crítica:

"Doña Estefaldina odia a los masones, reza por que mengüen las contribuciones. Reprende a las mozas si tienen galán. Oprime en las rentas a sus aparceros, los vastos salones convierte en graneros, da buenas palabras al que llora pan." 24

\section{LOS SIGNOS AUGURALES DE TRAGEDIA}

En las claves siguientes, Valle-Inclán emplea signos de indicio, ocultaciones intencionadas, augurios trágicos, en vez de representar o de escenificar la ejecución cruenta del crimen. Las sugerencias adversas se acumulan en los cuartetos de pie quebrado de "Tijeras abiertas"25. Doña Estefaldina se despierta sobresaltada, por el maleficio de su sueño con "Tijeras abiertas". Otros signos de augurio trágico se encadenan: el canto de la lechuza en e! "torvo alero" del palacio, la raposa que salta la barda, el nombre del Mal Espíritu...

El destino, la Ananké presentida, se impone en los cuartetos eneasilábicos de "La coima", con la multiplicidad de sus encuadres ambientales y de funtivos agenciales. La objetividad de las percepciones reales está sometida a un desajuste connotativo que nos transmite una intención satírica, paródica. Podemos comprobarlo en las primeras estrofas del poema:

"El gato dormita en la silla,

da un círculo al techo el quinqué;

la cornuda luz amarilla

dice en el cuarto su Ananké.

\footnotetext{
${ }^{24}$ Id., Id., p. 84.

${ }^{25}$ Id., Id., pp. 89-93.
}

"CUADERNOS DE ESTUDIOS GALLEGOS", Tomo XLI, Fascículo 106, Santiago 1993-94. 
Jergón con colcha floreada, recogida en blanquillo azul. Una mujer acurrucada posa la sien en el baúl.

Bajo la rama de olivera un Santo Cristo de latón, y bajo una moña torera, la falda maja y el mantón."26

Además del aparencial tipismo popular, el autor introduce signos de tensión dramática. "La cornuda luz amarilla" anuncia, agorera, la Ananké. El Jaque que entra a media noche, en la habitación de la "coima", nervioso, el gesto rasgado, se identifica como asesino de la infanzona, al mostrar "el puñal ensangrentado":

"Alienta el galán contra el muro; su ceja inquieta y montaraz palpita midiendo el seguro: le rasga un mal gesto la faz.

Lanza una risa baladrona el Jaque, y enseña el puñal ensangrentado. La bribona se enciende amorosa y carnal." 27

La autoría del crimen se aclara, decididamente, en la clave XII, titulada "El preso". Su larga serie de pareados de versos alejandrinos inicia el primer acto preparatorio del castigo del jaque. La pareja de la Guardia Civil conduce al preso, por el camino polvoriento. La selección de lexías y connotaciones, regidas por la voluntad innovadora del poeta, refuerzan la vinculación entre los rasgos físicos y la actitud del detenido:

"Entre guardias civiles, un hombre maniatado camina. Tiene el gesto soturno del malvado.

Sobre la frente torva como el testuz del toro, el zorongo de lienzo le pone algo de moro.

\footnotetext{
${ }^{26}$ Id., Id., pp. 95-96.

${ }^{27}$ Id., Id., p. 97.
}

"CUADERNOS DE ESTUDIOS GALLEGOS", Tomo XLI, Fascículo 106, Santiago 1993-94. 
Negros y siluetados los tricornios, parejos de la tarde poniente reciben los reflejos.

Una luz que aún define la $\mathrm{X}$ amarilla del correaje. Llegan cantares de una trilla." 28

\section{EL DRAMATISMO EXTREMO DE GARROTE VIL}

La sucesión compositiva de las secuencias cardinales del "Crimen de Medinica" se desborda, trágicamente, en la clave "Garrote vil"29. La tensión de la primera estrofa rompe el esplendor de la alborada, con el metálico repicar del martillo que clava el andamiaje del patíbulo. El estridente "¡Tan! ¡Tan! ¡Tan!" transmite el anuncio agorero de la venganza pública. El tablado de la ejecución, el temor patibulario sobre las rondas de tabaco y anís, se intensifica, simbólicamente, con la introducción del color cárdeno en el horizonte:

"El patíbulo destaca

trágico, nocturno y gris,

la ronda de la petaca

sigue a la ronda de anís,

pica tabaco la faca,

y el patíbulo destaca

sobre el alba flor de lis."

Con el ambiente dramático extremo, contrastan los elementos que transmiten un ambiente festivo: la áspera copla, el sonido de la guitarra, el "grito de la jota", el "morapio peleón", la canción del patriota, parecen apuntar hacia una morbosa complacencia, ante el espectáculo de la irreversible pena capital. Ante la "apicarada pelambre" que "se solaza muerta de hambre", se ofrece el manjar de los churros, introduciendo una nota de tipismo popular:

"Un gitano vende churros

al socaire de un corral,

asoman flautistas burros

las orejas al bardal,

\footnotetext{
${ }^{28}$ Id., Id., p. 101.

${ }^{29}$ Id., Id., pp. 107-110.
}

"CUADERNOS DE ESTUDIOS GALLEGOS", Tomo XLI, Fascículo 106, Santiago 1993-94. 
y en el corro de baturros

el gitano de los churros

beatifica al criminal."

La secuencia siguiente se endurece con el plano del reo en capilla. La fatal desesperanza, entre el rezo en latín del clérigo y la vela amarilla, se dramatiza con el sentido paródico de la lexía "da fin a la amarilla tortilla":

"El reo espera en capilla, reza un clérigo en latín, llora una vela amarilla, y el sentenciado da fin a la amarilla tortilla de yerbas. Fue a la capilla la cena del cafetín."

En el bosquejo del reo en la celda se consigue una perspectiva objetiva, directa, de la voz poética. La eliminación de las imágenes contribuye a enmudecer el cuadro. Sólo el verso tercero incorpora una fórmula de prosopopeya, al atribuir a las gotas de cera que caen de la vela encendida, la cualidad del llanto: "llora".

El protagonismo del color amarillo, de raíz solanesca, transmite un sentido dramatizador, intensificada con la relación entre los sintagmas "vela amarilla" y "amarilla tortilla". No olvidemos, por otro lado, dos indicios de este color: la etimología del latín amarus, relacionado con la bilis amarga y amarilla; y la atribución de efectos de mal agüero que posee este color en algunos contextos sociales.

\section{LA RECONSTRUCCIÓN DEL CRIMEN EN UN ROMANCE DE CIEGO}

Después de poetizar el proceso trágico del crimen de Medinica, ValleInclán, mediante un procedimiento de instancia delegada, nos ofrece una nueva versión en el romance de ciego ${ }^{31}$, ilustrado con un cartelón, pintado en cuatro escenas, con acentuada técnica esperpéntica, con "fondo de yema". La primera escena se plasma con una técnica fragmentada, de

\footnotetext{
${ }^{30}$ Id., Id., p. 110.

${ }^{31}$ El romance se titula "El crimen de Medinica". Cfr. ed. cit., pp. 113-117.
} 
simultaneísmo cubista: abren la puerta brazos armados, fieros puñales levantado, quinqué y mesilla volcados. Sale la dama desvelada, camisón blanco, verde chinela, con palmatoria. Este sincronismo se adensa en este tercero monorrimo, que transmite el encuadre vinculado con la estrategia goyesca:

"Azul de Prusia son las figuras y de albayalde las cataduras de los ladrones. Goyas a oscuras."

La segunda escena se complica con cuatro encuadres, diseñados con el mismo ritmo simultaneísta, dramatizado:

"En la cocina tienen doblada dos hombres negros a la criada: moño colgante, boca crispada.

Boca con grito que pide tila, ojos en blanco, vuelta pupila, una criada del Díes Illa.

Entre los senos encorsetados, sendos puñales tienen clavados, de rojas gotas dramatizados.

Pompa de faldas almidonadas, vuelo de horquillas, medias listada:

las botas nuevas muy bien pintadas."

El crimen de Estefaldina se registra en los encuadres de la escena tercera. La encamisada "arrastrada de los cabellos" aparece esperpentizada en el último terceto:

"Manos abiertas en abanico, trágicas manos de uñas en pico:

los cuatro pelos en acerico."

En la escena última introduce al bandolero, colgando su faja, con una técnica de Solana; representa su espanto al reconocer el relicario familiar. Este signo de indicio se confirma en el "comento" final. El bandolero ha dado muerte a su propia madre. Estos tres decasílabos, dramatizan su situación: 
"¡Madre! Qué grito del bandolero.

¡Muerta! Qué brazos de desespero.

¡Sangre! A sus plantas corre un reguero." ${ }^{32}$

\section{LA REPRESENTACIÓN DEL MUNDO POPULAR MADRI- LEÑO}

La confirmación del cambio de estética en La pipa de kif se concreta en las variadas interpretaciones del contexto urbano popular madrileño. Valle-Inclán desmitifica sus visiones modernistas. Emplea una perspectiva externa; pero los cuadros referenciales representados se alteran con un proceso de deformación. La caricatura, el sarcasmo, la parodia, el humor trágico, están actuando sobre el protagonismo colectivo. Y el universo marginado madrileño se diseña con una decidida intención melodramática. La visión intensificada, múltiple, está conseguida con especial efectividad en las claves "Vista madrileña" (XV) y "Resol de verbena" (XVI).

La voz poética impone la técnica esperpéntica o preesperpéntica, en el largo discurso de "Vista madrileña"33. Las secuencias de versos hexasílabos, marcados con el sonsonete de rimas inarmónicas, nos transmiten multiplicidad de sensaciones visuales, auditivas, olfativas y sinestésicas.

Las percepciones olfativas inundan la "tarde calina". Los vapores de mojama, cecina, horchata, limón, "torraets", altramuz, alternan con el concierto de cantos, maullidos, notas desafinadas de instrumentos musicales, gritos estridentes.

Desde una perspectiva cambiante, desde la altura, como una evocación del Diablo Cojuelo, la mirada del poeta contempla los tejados, las buhardillas; desciende a las calles, a la taberna de Serapio, a la "murga de la esquina".

El discurso narrativo se activa con el ritmo apremiante del protagonismo colectivo. La representación sociológica de un Madrid absurdo, hambriento, multiforme, se anticipa a la exploración esperpéntica de Luces de bohemia.

\footnotetext{
${ }^{32}$ La pipa de kif, ed. cit., p. 117. El terceto final confirma el matricidio:

"iSu propia madre! Canta el coplero.

Y el viejo al mimo le signa austero,

corta la rosa del Romancero"

${ }^{33}$ La pipa de kif, ed. cit., pp. 121-127.
}

"CUADERNOS DE ESTUDIOS GALLEGOS", Tomo XLI, Fascículo 106, Santiago 1993-94. 
Las acciones gestuales aparecen encadenadas. Así, el señor Serapio escancia el "morapio con esplendidez". Un zapatero de "agria sonrisa" silba "La Internacional" a un jilguero; la vieja tuerta sacude un ruedo en el umbral. Se produce, en algunas secuencias, un efecto de absurdidad con un desplazamiento de calificaciones, como este ejemplo:

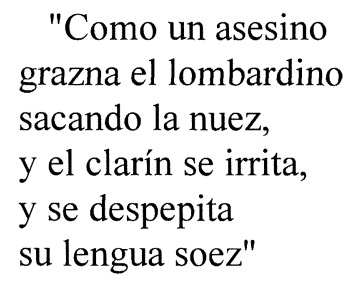

Valle-Inclán desemiotiza la lengua, al sustituir los códigos elaborados por formas diastráticas, y utiliza, con resultados muy productivos, la vinculación de los relieves fonemáticos y los valores semánticos. Esta reelaboración lingüística se concreta en un creciente antilirismo, presente en distintas estrofas del discurso poético. Puede constatarse esta intención en la copla hexasilábica siguiente:

"El acetileno, ojos de veneno, arde bajo un tul. Tembleque y gatera, en la tasca impera con su blusa azul: gatera y tembleque preside el guateque de una ronda ful." 34

Los encuadres se suceden: la ostentación de la tabernera, la "vieja tuerta", que azota el ruedo, el perro que rasca la oreja. La mirada degradante sobre la protagonista, su paródico baile con una silla, su semejanza con el "cuco del reloj", se reflejan en esta estrofa:

"Una chica fea -que la tifoidea pelona dejóbaila en la guardilla, arrastra una silla, y ella es el gachó.

${ }^{34}$ Id., Id., p. 124.

"CUADERNOS DE ESTUDIOS GALLEGOS", Tomo XLI, Fascículo 106, Santiago 1993-94. 
Sale al ventanuco, y parece el cuco que habla en el reló." 35

El antilirismo actúa sobre los sucesivos enfoques de los espacios urbanos. Incide en los personajes marginados, marcados por taras físicas. Resaltan los cuadros humildes, iluminados por luces de "cromo y añil", por reflejos hostiles, alejados de toda plasticidad modernista.

La penúltima estrofa de esta clave es un ejemplo de esta tendencia poetizadora:

"La fuente de hierro;

en la fuente, un perro

lanzando su orín.

En los hoyos secos .

de álamos entecos,

latas con hollín.

De andamios remotos,

los xantares, rotos

al calvar el zin." 36

De las tapias amarillas, el color de Castilla, brota "un reflejo hostil". Las desbaratadas carretas, pintadas de azul, avanzan entre el polvo del camino y los roncos juramentos de los carreteros. Un perro orina en la fuente de hierro. En los remotos andamios resuena el martilleo roto de "clavar el zinc". Y este diseño final del ámbito vespertino, cuando resplandece la luz del planeta Saturno:

"Lejano, lejano, un tejar albano con humo y resol. Algún pobre huerto, con su perro muerto, destripado el fol.

Lejano y nocturno, el viejo Saturno enciende el farol."

${ }^{35}$ Id., Id., p. 125.

${ }^{36}$ Id., Id., p. 126.

"CUADERNOS DE ESTUDIOS GALLEGOS", Tomo XLI, Fascículo 106, Santiago 1993-94. 


\section{LA INTERPRETACIÓN DE LAS VERBENAS}

Los factores geosociales se amplían, se adensan y dinamizan en "Resol de verbena". "Resol de verbena" ${ }^{37}$, nos transporta a un ambiente de fiesta que se desplaza al "campo amarillo de cromo", con la merienda y la música sobre el camino. Los modelos inspiradores son, sin duda, la pradera de San Isidro, las verbenas de la Paloma y de San Antonio de la Florida. En las secuencias se engarzan los contenidos prototípicos del artículo de costumbres. Pero Valle-Inclán transforma los convencionalismos del género con la distorsión de la lengua, la parodia de lo sentimental y el persistente antilirismo.

En la interpretación de la estampa vespertina, la percepción del paisaje, desmitificado, connotado con rasgos humanos: la luz de la tarde es "ingrata", el azul de los olivos es "cobarde", la tonalidad del campo es de "cromo". En el segundo cuarteto, el encuadre se desmitifica con lexemas y sintagmas intensificadores:

"Se merienda sobre el camino

entre polvo y humo de churros,

y manchan las heces del vino

las chorreras de los baturros."

La percepción de la verbena aparece multiplicada, en contrapunto, a lo largo del sistema octosilábico de rimas consonánticas, frecuentemente inarmónicas. Sobre la música de la jota y la nota "dramática" del baile, se impone la atracción del tiovivo, en las estrofas cuarta y quinta:

"El tiovivo su quimera

infantil erige en el raso:

en los caballos de madera

bate el reflejo del ocaso.

Como el monstruo del hipnotismo

gira el anillo alucinante,

y un grito pueril de histerismo

hace a la rueda el consonante. ${ }^{138}$

El poeta aplica dos procedimientos expresivos opuestos. En el primer cuarteto, la "calesita", "quimera infantil", resalta bajo el efecto lumínico,

\footnotetext{
${ }^{37}$ La pipa de kif, ed. cit., pp. 131-135.

${ }^{38}$ Id., Id., p. 132.
}

"CUADERNOS DE ESTUDiOS GALLEGOS", Tomo XLI, Fascículo 106, Santiago 1993-94. 
de herencia impresionista. Los versos de la segunda secuencia se transmutan en una imagen compleja. La sugestión hipnótica del juego se expresa por una lexía desmesurada - "el monstruo del hipnotismo"-, y el girar del "anillo alucinante" provoca el grito histérico. La imagen encadenada es factible de representar: La sugestión hipnótica del juego del tiovivo se expresa en los fragmentos léxicos, "Como el monstruo del hipnotismo / gira el anillo alucinante."

La serie de cuartetos eneasilábicos de "Resol de verbena" interpretan nuevas realidades del cinturón suburbano madrileño. El autor adopta una perspectiva externa, objetiva, para recrear un clímax festivo. Lexemas de expresión popular resuelven las notas dramáticas del baile, del ritmo de la jota, el girar del "anillo alucinante" del tiovivo; los pregones de azucarillo y aguardiente, de la suerte del pajarito; el ondear de los columpios. El código lingüístico restringido predomina en la cadena secuencial.

Valle-Inclán parte de sus propias vivencias de la verbena de San Antonio de la Florida; y las interpreta en una multiplicidad de encuadres. Para Melchor Fernández Almagro ${ }^{39}$ su "expresión dura, seca y agria" recuerda "en ocasiones un cierto modo quevedesco de percibir la vida".

Los rasgos antipoéticos se engarzan en las estrofas: las fritangas, las heces del vino, la desnuda navaja del chulo, la costurera que enseña "la liga rosada", los encadenados pregones; y el plano sombrío, desgarrado, esperpéntico, del idiota al borde del camino:

"Brama el idiota en el camino,

y lanza un destello rijoso

bajo el belfo el diente canino

recordando a Orlando Furioso." 40

La atracción de la fiesta se transmite con una pluralidad de percepciones: los pregones de ensalmos, refrescos, claveles, la "foca y el hombre gigante". Y termina el cuadro costumbrista de las fritangas, conformado en el último cuarteto del discurso:

"Se infla el buñuelo. La aceituna

aliñada reclama el vino,

y muerde el pueblo la moruna

rosquilla, de anís y comino."41

\footnotetext{
${ }^{39}$ Cfr. Vida y literatura de Valle-Inclán, Madrid, Taurus, 1966, pp. 174-175.

${ }^{40}$ La pipa de kif, ed. cit., p. 134.

${ }^{41}$ Id., Id., p. 135.
}

"CUADERNOS DE ESTUDIOS GALLEGOS", Tomo XLI, Fascículo 106, Santiago 1993-94. 
Las secuencias siguientes del discurso estructuran un modelo de simultaneísmo. El chulo alborota el baile, y entre "los registros de la jota está desnuda la navaja". La pareja de la daifa y el soldado se ilusionan con "la suerte del pajarito". La costurera endomingada da su risa en el columpio, y el estudiante se enamora.

La técnica expresionista es eliminada, sobre todo en la luminosidad vesperal que se enciende en estos versos:

"Corona el columpio su juego

con cantos. La llanura arde:

tornose el ocaso de fuego,

los nardos ungieron la tarde.

Por aquel rescoldo de fragua

pasa el inciso transparente

de la voz que pregona: - $i$ Agua,

azucarillos y aguardiente!."42

Este alarde luminoso introduce la figura de dos entes mitológicos: Eros ofrece una guirnalda a la niña que se columpia, y en la "onda azul" del columpio "asoma la frente vespertina de una sirena"43. Pero la luminosidad de la secuencia se convierte en esperpento en los siguientes versos:

"Brama el idiota en el camino,

y lanza un destello rijoso,

bajo el belfo, el diente canino, recordando a Orlando Furioso."

El clima popular se retoma en las secuencias finales. Los pregones, anunciados con "jagua, azucarillos y aguardiente!", se encadenan, superpuestos, confundidos, como la "guirnalda de babeles" que reproducimos:

$" ¡$ Un real, la cabeza parlante!

¡A la suerte del pajarito!

¡La foca y el hombre gigante!

¡Los gozos del Santo Bendito!

¡Naranjas! ¡Torrados! ¡Limones!

¡Claveles! ¡Claveles! ¡Claveles!"44

${ }^{42}$ Id., Id., pp. 133-134.

${ }^{43}$ Id., Id., p. 134.

${ }^{44}$ Id., Id., p. 135.

"CUADERNOS DE ESTUDIOS GALLEGOS", Tomo XLI, Fascículo 106, Santiago 1993-94. 


\section{LA TIENDA DEL HERBOLARIO}

Las últimas claves de La pipa de kif nos acercan al límite de la realidad, instalándose en la línea del frágil equilibrio entre lo consciente y lo subconsciente.

El largo discurso de "La tienda del herbolario"45 se apoya en tres ejes semánticas: el exotismo de la rememoración sensorial de las experiencias americanas, la magia negra y las formas rituales en general, y la acción obnubiladora de los estupefacientes. La serie continuada de pareados eneasilábicos nos transmite la transposición de percepciones cálidas, goces insospechados, "ardientes esencias", delirios y tentaciones.

Valle-Inclán, en esta clave XVII, abre una nueva frontera de exploración, conformada por la expresión de sucesivos estados de enajenamiento, de alucinación. Se inscribe, por lo tanto, en una de las tendencias de la modernidad.

La cueva del herbolario es un laboratorio de sensaciones mareantes. El "alumbramiento" de los estupefacientes, de los "cañamones verdes", se mezcla con la "ciencia negra de Caldea", con los hechizos. Los hechizos, los olores mareantes, los ritos ancestrales, la arcana acción de los estimulantes, rigen los comportamientos descontrolados:

(pulque) (placeres de Baco) es: celo para las mujeres, melancolía de los indios, bailes lúbricos, duelos sangrientos en las pulperias.

Algunas unidades de "La tienda del herbolario" representan procesos de metamorfosis, cambios de comportamiento humano, sueños, pesadillas, visiones, que son una anticipación de ciertas creaciones surrealistas. La secuencia décima encadenará las distintas alucinaciones. La fuerza "energética" de la dura fibra de la coca envalentonaba a los araucanos, insensibilizaba a Francisco Pizarro. Bajo los efectos del zumo de la pita, del pulque, del jugo narcotizante de las cabezas de las adormideras, se metamorfosean las realidades, se generan mutaciones fantásticas, paraísos artificiales y farsas funambulescas, con connotaciones trágicas:

"El opio evoca sueños azules,

lacas, tortugas, leves chaúles;

Ojos pintados, pies imposibles, lacias coletas, sables terribles;

${ }^{45}$ Id., Id., pp. 139-151.

"CUADERNOS DE ESTUdios GALLEGOS", Tomo XLI, Fascículo 106, Santiago 1993-94. 
Verdes dragones, sombras chinescas, trágicas farsas funambulescas;

Genuflexiones de mandarines;

sabias princesas en palanquines..." ${ }^{46}$

La percepción influida por los opiáceos nos transmite una visión móvil que se expresa con la introducción de una sucesión de percepciones oníricas. El opio evoca "sueños azules", "ojos pintados", "lacias coletas", "sables terribles", "verdes dragones", "trágicas farsas funambulescas", "genuflexiones de mandarines", "sabias princesas en palanquines".

La lexía "largas farsas funambulescas" resume, claramente, la nueva estética esperpéntica, apuntada en los discursos de las otras claves. La secuencia siguiente intensificará y subrayará el sentido de dicha lexía:

"¡Verdes venenos! ¡Yerbas letales de Paraísos Artificiales!

A todos vence la marihuana, que da la ciencia del Ramayana.

¡Oh! marihuana, verde neumónica, cannabis índica et babilónica.

Abres el sésamo de la alegría, cáñamo verde, kif de Turquía.

Yerba del Viejo de la Montaña, el Santo Oficio te halló en España.

Yerba que inicias a los faquires, llena de goces y Díes Ires.

¡Verde esmeralda -loa el poeta persa- tu verde vistió el profeta!

(Kif -yerba verde del persa- es el achisino bhang bengalés.

Charas que fuma sobre el diván, entre odaliscas, el Gran Sultán.)"177

${ }^{46}$ Id., Id., p. 149.

${ }^{47}$ Id., Id., pp. 150-151.

"CUADERNOS DE ESTUdios GALLEGOS", Tomo XLI, Fascículo 106, Santiago 1993-94. 
Los "verdes venenos", las "yerbas letales" potencian la creación de "paraísos artificiales". Pero la marihuana es la fuerza desencadenante de la alucinación, de la magia aparente y el delirio onírico. La hierba aparece denominada con una gran variedad de nombres que remiten a su exotismo y a sus efectos, por ejemplo: "Abres el sésamo de la alegría, cáñamo verde", "kif de Turquía", "Kif -yerba verde del persa- es el achisino bhang bengalés".

\section{LA ESTÉTICA MODERNA DE ROSA DEL SANATORIO}

Una de las claves de la inspiración poética valleinclanesca es el efecto de los alucinógenos, de los fármaços obnubilantes y de los tóxicos. Con la somnolencia, con la pérdida de la consciencia, se abre un mundo subyacente que vacila entre el efecto alienante del kif de la primera clave, y las sensaciones adormecedoras del cloroformo de "Rosa de sanatorio"48. Esta composición, última clave del corpus que analizamos, en una síntesis de distintos procedimientos de creación modernos. Podemos comprobarlo en el texto:

"Bajo la sensación del cloroformo me hacen temblar con alarido interno, la luz de acuario de un jardín moderno y el amarillo olor del yodoformo.

Cubista, futurista y estridente, por el caos febril de la modorra vuela la sensación, que al fin se borra, verde mosca, zumbándome en la frente.

Para mis nervios, con gozoso frío, el arco de lunático violín; de un sí bemol el transparente pío

tiembla en la luz acuaria del jardín, y va mi barca por el ancho río que separa un confín de otro confín."

${ }^{48}$ Id., Id., pp. 155-156.

"CUADERNOS DE ESTUDIOS GALLEGOS", Tomo XLI, Fascículo 106, Santiago 1993-94. 
En el texto, que corona el discurso poético de La pipa de kif, ValleInclán sugiere distintos problemas estéticos. La estructura repite la larga tradición del soneto endecasilábico. No varían los cuartetos abrazados, aunque cambia de rimas, ajustadas a este esquema:

A B B A : C D D C

Los tercetos riman en forma encadenada:

E F E : F E F

Se mantienen, también los esquemas rítmicos tradicionales. En la combinación polirítmica, predominan los endecasílabos heroicos, melódicos y sáficos.

Frente a esta pervivencia de una composición clásica, en la selección lexical, en la función connotativa, se eluden las sensaciones plásticas de tipo modernista. La moderna estética del poeta se manifiesta en lexemas y lexías que representan una preocupación por nuevos modos de expresión literaria, tanto en lo que se refiere a las interpretaciones espaciales y objetuales, como los que contribuyen a la creación de una esfera obnubiladora a lo largo del texto.

La interpretación de referentes espaciales está presente en los siguientes ejemplos: "luz de acuario de un jardín moderno", "luz acuaria del jardín" y "arco de lunático violín". El estado de alteración nerviosa aparece en los siguientes ejemplos: "amarillo olor del cloroformo", "caos febril de la modorra", "pasa mis nervios, con gozoso frío".

La voz poética, que actúa como agente en el espacio crítico del sanatorio, describe los estados de delirio, de inconsciencia, regidos, lingüísticamente, por la primera persona del presente, en esta lexía: "me hacen temblar". La inhalación del cloroformo marca y condiciona el paso de la situación objetivable al febril caos interno. El segundo cuarteto contiene una nueva fase de la pesadilla. El cloroformo continúa actuando en el "caos febril de la modorra". En los tercetos, la crisis y la tensión se mantiene con nuevas pesadillas.

El proceso de desarrollo de las tensiones del soneto se visualiza en el esquema siguiente:

Sensación del cloroformo: (el yo) tiembla con alarido interno (luz de acuario de un jardín) (olor del yodoformo). Por el caos febril de la modorra: vuela la sensación (cubista, futurista, y estridente), (la sensación) (verde mosca) zumbándome en la frente.

El proceso de tensión continúa en los tercetos, con tres niveles de incidencias distintos:

"CUADERNOS DE ESTUDiOS GALLEGOS", Tomo XLI, Fascículo 106, Santiago 1993-94. 


\begin{tabular}{|c|c|c|}
\hline$-a-$ & $-b-$ & $\begin{array}{c}-c- \\
\text { (plano imaginado) }\end{array}$ \\
\hline el arco de lunático violín & $\begin{array}{l}\text { el transparente } \\
\text { sonido }\end{array}$ & $\begin{array}{l}\text { mi barca va por el ancho rio } \\
\text { que divide un confin de otro }\end{array}$ \\
\hline pasa mis nervios & & confin \\
\hline con gozoso frío & $\begin{array}{l}\text { tiembla en la luz del } \\
\text { acuario }\end{array}$ & \\
\hline
\end{tabular}

\section{LAS IMÁGENES PRESURREALISTAS}

En algunas claves de La pipa de kif, la inspiración de Valle-Inclán está dominada por la acción de los alucinógenos, por mutaciones obnubiladoras, dentro de una trayectoria circular que se inicia con la clave que lleva el mismo título del libro, centrada en la acción del "veneno" alucinógeno del haxix, y termina en las sensaciones internas generadas por el cloroformo. La función básica de la última clave, "Rosa del sanatorio", es el "estado de subconsciencia", producido por el efecto clorofórmico y el "amarillo color" del antiséptico yodoformo. Esta acción está vinculada con algunas creaciones vanguardistas; pero también deriva de la literatura decadentista finisecular, cultivado por el propio escritor gallego en la primera etapa.

Valle-Inclán inicia el segundo cuarteto del discurso con términos claves: "Cubista, futurista y estridente", pero no puede referirse al surrealismo, porque su primer manifiesto se difunde cinco años más tarde, en 1924. A pesar de esta diferencia de fechas, dos críticos literarios han planteado el análisis de "Rosa de sanatorio", desde la perspectiva del surrealismo.

Emilio González López ${ }^{49}$, en su estudio sobre la poesía valleinclanesca, rotula el capítulo correspondiente con este título: "El marco surrealista de La pipa de kif: búsqueda de la subconsciencia"50. Parece evidente que la funcionalidad de la subconsciencia no puede vincularse con un movimiento literario que aún no existe. Sin embargo, González López, al referirse a "Rosa de sanatorio", afirma que: "... la técnica, el lenguaje, las imágenes y el estilo entran ya en el surrealismo".

No precisa los códigos que activan estas supuestas imágenes surrealistas.

${ }^{49}$ La poesia de Valle-Inclán. Del simbolismo al expresionismo, San Juan de Puerto Rico, Ed. Universitaria, 1973.

${ }^{50}$ Id., Id., pp. 72-75.

"CUADERNOS DE ESTUDIOS GALLEGOS", Tomo XLI, Fascículo 106, Santiago 1993-94. 
Pero plantea el salto entre la conciencia y los "mundos imaginarios de la subconsciencia". Y resalta que frente al poder mágico de los estupefacientes de la primera clave del libro, la última composición:

"...trata de darnos ya, por medio de imágenes, totalmente vanguardistas, las notas de ese mundo irreal que buscaba, en el que el jardín tiene una luz de acuario y olor amarillo del yodoformo es el que domina en este nuevo mundo..." 51

Bastantes años más tarde, en 1984, el profesor José Servera Baño publica, en la revista Caligrama $^{52}$, el artículo "Un hipotético soneto surrealista de Valle-Inclán. Análisis de "Rosa de sanatorio". Alude a la tesis de González López, pero puntualiza que su estructura métrica tradicional contradice su filiación surrealista. Sin embargo, resalta en "Rosa de sanatorio" la mezcla de componentes tradicionales y elementos surrealistas. Y, al final de su análisis, vuelve a insistir en la presencia de estos rasgos, que denomina "surrealistas":

1.- La pérdida de la conciencia del poeta, en la inconsciencia del tratamiento clínico.

2.- Predominio de sensaciones oníricas.

3.- El versificador en estado "alucinógeno" de libertad expresi$\mathrm{va}^{53}$.

${ }^{51}$ Id., Id., p. 72.

${ }^{52}$ Vol. I, 1-2, Palma de Mallorca, Filología Hispánica, p. 184.

${ }^{53}$ Id., Id., pp. 63-64.

"CUADERNOS DE ESTUDIOS GALLEGOS", Tomo XLI, Fascículo 106, Santiago 1993-94. 